Original Research Paper

\title{
Profitability Analysis of Small-Scale Beekeeping Firms by Using Life Cycle Costing (LCC) Methodology
}

\author{
Alfio Strano, Teodora Stillitano, Anna Irene De Luca, Giacomo Falcone and Giovanni Gulisano \\ Department of Agriculture (AGRARIA), Mediterranean University of Reggio Calabria, Reggio Calabria, Italy
}

\author{
Article history \\ Received: 11-07-2015 \\ Revised: 22-07-2015 \\ Accepted: 24-7-2015 \\ Corresponding Author: \\ Teodora Stillitano \\ Department of Agriculture \\ (AGRARIA), Mediterranean \\ University of Reggio Calabria, \\ Reggio Calabria, Italy \\ Email: teodora.stillitano@unirc.it
}

\begin{abstract}
Increasingly, beekeeping sector attracts attention due to its potentialities linked to several aspects: Environmental benefits, commercial value and of promotion of rural development. Indeed, among the smallscale agro-food chains, beekeeping plays a significant role, especially in rural context, where the diversification of farms activities can be provide a relevant integration of income. However, frequently, apicultural activities are characterized by several weaknesses ascribable to the fragmented production, difficulty of marketing actions and lack of training of operators. These problems are particularly present in Calabria region in South Italy where, anyway, thanks to several suitable climatic conditions, high quality standards of honey are obtained. So, in order to achieve the efficiency of firms and to improve the business beekeeping production it is necessary to arrange a production system that takes into account the real availability of material resources. The economic behavior of beekeepers and their investment choices are fundamental to accomplish a successful business that, more and more today, needs to high productivity of labor and adequate equipment, guaranteed by optimization of production factors. This paper has a two-fold purpose: Firstly, it aims to conduct an economic analysis of beekeeping activities, as significant small-scale agri-food chain in southern Italy, by analyzing the production, processing and packaging of honey in farm realities of Calabrian region. The second objective of this paper is to evaluate the profitability of investments realized in beekeeping firms. For this purpose, a joint use of Life Cycle Costing (LCC) methodology and economic indicators was applied in order to analyze in detail cash outflows linked to each phase of honey production system (planning, management and disposal) and to identify key elements that can improve the farm management. Results showed the economic viability of the investment and a suitable level of profitability. Furthermore, the analysis carried out confirms these methodologies as useful tools to support investment choices and to improve economic performances of management strategies of agro-food producers.
\end{abstract}

Keywords: Economic Profitability, Investment Assessment, Life Cycle Costing (LCC), Small-Scale Agro-Food Chains, Beekeeping

\section{Introduction}

According to official statistics, beekeeping activities are practiced, more or less intensely, in almost all countries at global level. The world honey production, in terms of prevailing beekeeping production, has reached, in 2013, a value equal to 1.66 million tons (FAO, 2015).

Looking at the distribution by geographical area, as designed by FAO (2015), Asia represents the largest honey producer, with $45.7 \%$ of total supply, of which China accounts for about $59.2 \%$, followed by Europe with about $22.4 \%$ of production. Among European countries, Ukraine and Russia are the most important producers, with respectively 19.8 and $18.4 \%$ of European production.

The American production reaches the third position with about $20.0 \%$ of world production especially for the contribution of Argentina (24\%) and USA (20.4\%).

The fourth position is occupied from Africa, with $10.2 \%$ of world production, while the remaining $1.8 \%$ is produced from Oceania. In Italy, beekeeping is 
increasingly relevant in terms of both income production and diversification of farming activities and as useful ecosystem service. According to ISTAT (2010a), Italian honey production in 2010 amounted to 12,200 tons, of which $14.8 \%$ came from Lombardia, $13.1 \%$ from Emilia Romagna, 11.5 and 9\% respectively from Piemonte and Toscana. Among the small-scale agro-food chains, beekeeping plays a significant role especially in rural context where the diversification of farms activities can be provide a relevant income integration. This is the case of Calabria region in South Italy where, due to several suitable environmental conditions, high quality standards of honey are obtained. However, some weakness in beekeeping sector can be found in fragmentation of production and the consequent difficulty of marketing actions, as well as the lack of training of operators (Regione Calabria, 2010a). So, in order to achieve the efficiency of firms and to improve the business beekeeping production it is necessary to arrange a production system that takes into account the real availability of material resources- e.g., hives, equipment, materials, transportation, infrastructure, energy sources and buildings (Pocol et al., 2012).

Therefore, as well as for other sectors, also in beekeeping the economic behavior of entrepreneurs and their consequent investment choices are fundamental to accomplish a successful business that, more and more today, needs to high productivity of labor and adequate facilities and equipment (Ćejvanović et al., 2011), guaranteed by optimization of production factors.

Furthermore, apiculture attracts an increasing attention at international level, confirmed by the work of many scholars. Indeed, some of its benefits can be ascribable to the promotion of rural development, the positive environmental impacts, an high commercial value of products and the feed-back mechanisms aimed to the enterprises profitability (Saner et al., 2003; Notarnicola et al., 2004; Mogni et al., 2009; Pocol et al., 2011; Hilmi et al., 2011; Folayan and Bifarin, 2013; Fotso Kenmogne et al., 2014; Nazzi et al., 2014).

Furthermore, given the changes taking place in the agricultural sector, the development of innovative ways can be useful to create value-added for the competitive repositioning of agricultural enterprises (Marotta and Nazzaro, 2012) and in particular for beekeeping activities. According to Van der Ploeg et al. (2002), specific strategies of management, such as "broadening", "deepening" and "regrounding" mechanisms, allow farmers to seek advantageous strategies outside the traditional patterns of agriculture. The diversification of agricultural practices arises, therefore, as a necessity for the enhancement of production factors employed (Sotte, 2006).

In particular, through "deepening", apicultural farms can increase profitability and adding value to their raw agricultural products. To this aim, beekeepers need to focus all efforts on production for example by creating short supply chains, by improving quality productions and through the on-farm processing (Van der Ploeg, 2006). The adoption of these strategies entails a careful analysis of business choices by the farmer and the availability to consider new management layouts.

The traditional approaches to capital investment appraisal does not permit a full assessment since they could exclude some phases of the useful life of the project (Gluch and Baumann, 2004). Life Cycle Costing (LCC) approach allows a detailed viability assessment of the investment projects considering all costs associated to the life cycle of investment (acquisition, operation and disposal) (Dhillon, 1989). Based on this definition, the life cycle concept is considered from the buyer/user point of view which takes into account all cost typologies incurred following the initial investment (Notarnicola et al., 2009), by optimizing the economic performances of enterprises (Huppes et al., 2004).

Starting from the end of the last century, the applications of LCC in firm analysis are increased (Dhillon, 1989), confirming the interest in this technique born in the field of management accounting for the discounted cash flows analysis in acquisition of durable goods (Notarnicola et al., 2009). In 2002, SETAC strengthened the attention in LCC and a Code of Practice was drawn up in order to define the specific objectives of LCC methodology (Rebitzer and Seuring, 2003). Three different approaches were recognized: Conventional LCC, whereby the economic value as an internal cost is strictly considered in terms of the life cycle of a product; Environmental LCC, that is, always, accompanied by a complementary Life Cycle Assessment (LCA) assessment and it is based on an evaluation of all costs, including externalities; Societal LCC, which assesses internal and external costs in combination with LCA and it also includes the involvement of government agencies not directly responsible of the production system (Ciroth et al., 2008; Lichtenvort et al., 2008).

Currently, different harmonization criteria are available for the numerous fields of Conventional LCC applications; they are based on the theory of systems engineering and are focused on the evaluation and comparison of alternative technologies. Among these approaches, International Organization for Standardization define LCC as a methodology for the systematic economic appraisal of products/processes (ISO, 2008) and they classify all costs into four main categories: (i) construction costs; (ii) management costs; (iii) maintenance costs; (iv) end of life costs. However, a standardized methodology and specific guidelines on the procedures to calculate and compare costs do not yet exist (Lichtenvort et al., 2008). 
As already mentioned, LCC methodology was used, originally, in engineering-industrial fields and, in recent years within the international scientific debate, it has gained increasing interest in application to economic sustainability assessment of agro-food firms. For example, some scholars (Iotti and Bonazzi, 2014a; 2014b) employ LCC to evaluate all costs associated with farm investments in each stage of production by analyzing three different components: The building component, the plant management and the processing phase.

Furthermore, there is an ever-growing attention for LCC use in association with environmental assessment carried out through LCA. For example, in the case of olive-oil production system, Notarnicola et al. (2004) and Mohamad et al. (2014) analyzed the environmental profiles and business costs of different farm management methods (organic and conventional); De Gennaro et al. (2012) compared two innovative models of olive growing (intensive and super-intensive) in order to identify the best economic and environmental performance. The citrus production systems are analyzed by Strano et al. (2013a) and De Luca et al. (2014; 2015) performing a joint LCA and LCC analysis applied to different scenarios of Clementine production (organic, conventional and integrated) and also by Pergola et al. (2013) that analyzed the production of lemons and oranges. Regarding wine grape production, Strano et al. (2013b) and Falcone et al. (2015) compared the economic and environmental performance of farming techniques in organic and conventional farming systems.

The present study has a two-fold purpose: firstly, it aims to conduct an economic analysis of beekeeping activities as significant small-scale agri-food chain in southern Italy, by analyzing the production, processing and packaging of honey in farm realities of Calabrian region. The second objective of this paper is to evaluate the profitability of investments realized in beekeeping firms through a joint use of LCC method and economic indicators, in order to identify key elements that can improve the farm management.

The originality feature of the study is ascribable to the lack of similar analysis for the same context of production (for Italian territory and beekeeping sector) and to the innovative methodology implemented.

The study could have advantageous implications for beekeepers and honey processors in terms of support to farmer's decisions by identifying novel business strategies (e.g., supply chain integration strategies) to improve the economic performance of firms.

\section{Materials and Methods}

\section{Case-Study}

Among the small-scale agro-food chains in Calabria region (South Italy), beekeeping plays a significant role in the agriculture sector. Due to the suitable environmental conditions, the favorable climate, the limited pollution and the copious biodiversity of nectar species, high quality standards of honey are obtained.

There is a wide range of plant species-such as citrus fruits, exotic plants, herbs and Mediterranean maquisthat plays a role of extreme importance in the honey production with high organoleptic properties (Ragusa and Russo, 1989). The most common varieties of honey, most of which are recognized as traditional Italian products, are derived from essences of citrus, chestnut, eucalyptus, wildflower and Sulla. The importance of beekeeping in Calabrian territory is also confirmed by official statistical data, which show significant increases in the quantities of honey produced in the region.

According by ISTAT (2010b) the regional production of honey amounts to 600 tons, accounting for $4.9 \%$ of the national total, which compared to the previous year, is increased of $20 \%$. However, despite the high vocation of the region for honey production, since the first half of the 1980 's, the beekeeping sector has been suffering by a deep crisis due to several reasons.

Firstly, the Varroa destructor infestations, a mite present in all apiaries in the region that, in the absence of appropriate control measures, causes huge losses to beekeeping. Moreover, further weaknesses of the sector are represented by the fragmentation of production and the consequent difficulty of marketing actions, as well as the lack of training of operators, which, often, are parttime operators or hobby beekeepers (Ragusa and Russo, 1989; Sturiale, 1989; Regione Calabria, 2010a).

An additional critical factor is the limited presence of associative structures able to concentrate supply and to create value-added along the several phases of production, up to the commercialization of honey. The structural and organizational difficulties of the sector involve high production costs and not remunerative selling prices, by conducting to a consequent decline in the income of beekeepers. In view of these drawbacks, specific interventions would be desirable to reduce the operating costs and to promote necessary investments in facilities and technologies of laboratories in order to improve the efficiency of honey extraction and packaging.

The present analysis focused the attention on the beekeeping sector in the province of Reggio Calabria (Fig. 1) that, according to Regional Register of Beekeeper (Regione Calabria, 2010b), represents, in $2010,31.8 \%$ of the total regional beehives (with a positive trend of $17.9 \%$, from 2008 to 2010 ).

Firms can be distinguished into three class sizes of beekeeping, in reference to the beehives number: from zero to 99, from 100 to 299 and over 300. The intermediate class is the most widespread, accounting for $43 \%$ of the total. From a survey conducted by the National Honey Observatory (Osservatorio Nazionale Miele, 2009), the province of Reggio Calabria counts up to $49.3 \mathrm{~kg}$ per beehive as unit yield. 


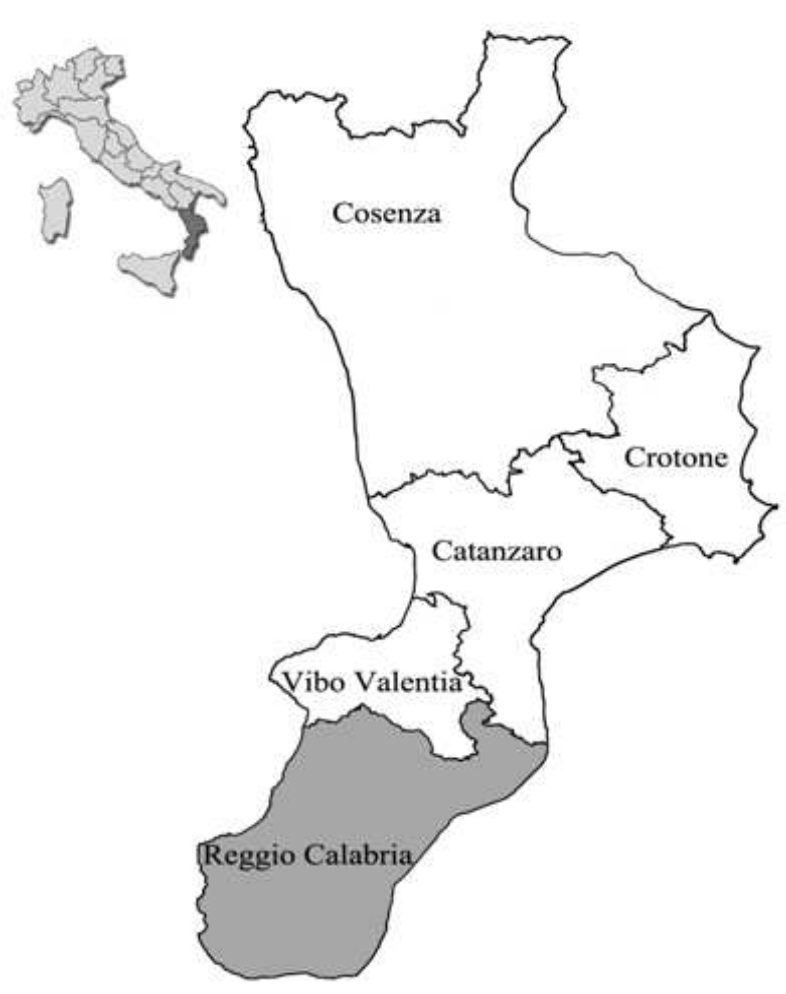

Fig. 1. Case-study area in Calabria region (South Italy)

The firms analyzed in this study belong to the intermediate class with an average equal to 270 beehives. In order to identify the structural characteristics, direct interviews with experts and privileged stakeholders (trade associations, wholesalers and beekeepers) were carried out. Results showed that about $80 \%$ of the firms are specialized, family run companies with permanent beekeeping. The interviews showed also that few firms are equipped with processing and packaging facilities.

Thanks to the interviews, it was possible to identify both the most common types of honey and the major distribution channels. More than $40 \%$ is represented by wildflower honey, about $30 \%$ is obtained from citrus fruits and the remainder is divided into eucalyptus and chestnut honey. With regard to sales channels, about $70 \%$ of the honey is for wholesale, $20 \%$ for large-scale distribution and the remainder $(10 \%)$ is sold directly by the enterprise.

Usually, every farm sell the yearly average production of honey in jerry can from $25 \mathrm{~kg}$ to $300 \mathrm{~kg}$ to wholesalers who, in turn, resell to large national companies which perform all the processes of packing and labelling. However, for large-scale distribution and retailing, $0.5 \mathrm{~kg}$ jars and $1 \mathrm{~kg}$ packs are used and are destined mainly to the local market.

For the case study, an investment was hypothesized for the construction of a honey processing and packaging plant. In order to acquire the information needed for the economic analysis, a sample firms has been carried out through a procedure of non-probability sampling with reasoned choice with an stratified allocation (Bailey, 1994), that allowed to define a sample distributed, proportionally, within the total population. Economicmanagement data, relating to the 2009-2011, were detected through a questionnaire administrated for both the field and laboratory phase. The average data obtained were used for the subsequent LCC and economic analysis.

\section{Life Cycle Costing (LCC) Analysis and Profitability Evaluation of Investments}

The LCC method adopted in this analysis follows the approach proposed by Iotti and Bonazzi (2014a), which divides the investment into three main components: building, plant and processing. The approach takes into account the time factor by discounting, with an appropriate discount rate $(r)$, the cash flows generated by each component during the overall life of the investment.

For the building component, which is the structure that will house the processing plant, the costs of start-up investment (acquisition costs), operating costs and profit (or loss if any) arising from the disposal (or retraining) are considered. In the following Equation 1 the first category of costs, i.e., design and construction costs of the building incurred in year 0 , are shown:

$B A C_{0}=B D C_{0}+B C C_{0}$

Where:

$B A C_{0}=$ Building Acquisition Cost (years 0$)$

$B D C_{0}=$ Building Design Cost (years 0)

$B C C_{0}=$ Building Construction Cost (years 0)

The operating costs related to the useful life (i.e., the Time Horizon "TH" from the $1^{\text {st }}$ to $n$ year) of the building, expressing for a generic year $(j)$, were calculated as follows:

$B O C_{j}=B E C_{j}+B M C_{j}+B O t C_{j}$

Where:

$B O C_{\mathrm{j}}=$ Building Operating Cost $($ year $j)$

$B E C_{\mathrm{j}}=$ Building Energy Cost (year $j$ )

$B M C_{j}=$ Building Maintenance Cost (year $j$ )

$\mathrm{BOtC}_{\mathrm{j}}=$ Building Other Cost (year $j$ )

In Equation 3 the profit (or loss) related to the building disposal is expressed:

$B D U_{n}=B D R_{n}-B D C_{n}$

Where:

$\mathrm{BDU}_{\mathrm{n}}=$ Building Disposal Useful (year $n$ )

$\mathrm{BDR}_{\mathrm{n}}=$ Building Disposal Revenue (year $n$ )

$\mathrm{BDC}_{\mathrm{n}}=$ Building Disposal Cost (year $n$ ) 
Therefore, Equation 4 represents the Total Building $\operatorname{Cost}\left(T B C_{T H}^{n}\right)$ :

$$
T B C_{T H}^{n}=B A C_{0}+\sum_{j=1}^{n} \frac{B O C_{j}}{(1+r)^{j}}-\frac{B D U_{n}}{(1+r)^{n}}
$$

Equation 5 was used in order to determine the total cost of the honey processing plant, with $\mathrm{TH}$ from the $1^{\text {st }}$ to $m$ years, due to the unlikeness between the useful life of the building ( $\mathrm{n}$ years) and the plant ( $\mathrm{m}$ years), as follows:

$$
T P l C_{T H}^{m}=P l D C_{0}+P l C C_{0}+\sum_{j=1}^{m} \frac{P l O C_{j}}{(1+r)^{j}}-\frac{P l D U_{m}}{(1+r)^{m}}
$$

Where:

$$
\begin{aligned}
T P C_{T H}^{m} & =\text { Total Plant Cost } \\
\text { PIDC }_{0} & =\text { Plant Design Cost (years 0) } \\
\text { PICC }_{0} & =\text { Plant Construction Cost (year0) } \\
\text { PIOC }_{\mathrm{j}} & =\text { Plant Operating Cost (year } j \text { ) } \\
\text { PIDU }_{\mathrm{m}} & =\text { Plant Disposal Useful (year } m \text { ) }
\end{aligned}
$$

In particular, the Plant Operating Cost $\left(\mathrm{PlOC}_{\mathrm{j}}\right)$ in (5) was distinguished in Variable Costs (VC) (that are dependent on the produced quantity $q$ ) and Fixed Costs (FC) (that are independent on the produced quantity $q$ ) so, according Equation 6, we get:

$$
\begin{aligned}
T P l C_{T H}^{m}=P l D C_{0}+P l C C_{0} & +\sum_{j=1}^{m} \frac{P l O V C_{j} q_{j}}{(1+r)^{j}} \\
& +\sum_{j=1}^{m} \frac{P l O F C_{j}}{(1+r)^{j}}-\frac{P l D U_{m}}{(1+r)^{m}}
\end{aligned}
$$

Equation 7 was used to calculate the Total Processing $\operatorname{Cost}\left(T \operatorname{Pr} C_{T H}^{m}\right)$ :

$$
T \operatorname{Pr} C_{T H}^{m}=\sum_{j=1}^{m} \frac{\operatorname{Pr} V C_{j} q_{j}}{(1+r)^{j}}+\sum_{j=1}^{m} \frac{\operatorname{Pr} F C_{j}}{(1+r)^{j}}
$$

Where:

$$
\begin{array}{ll}
\operatorname{PrVC}_{\mathrm{j}} \mathrm{q}_{\mathrm{j}} & =\text { Processing Variable Cost }(\text { year } j \text { ) } \\
\mathrm{q} & =\text { Produced quantity } \\
\operatorname{PrFC}_{\mathrm{j}} & =\text { Processing Fixed Cost }(\text { year } j \text { ) }
\end{array}
$$

By adding Equation 6 with Equation 7 we obtained the Manufacturing Cost of production $\left(M n C_{T H}^{m}\right)$.

To calculate the Total Investment Cost $\left(\operatorname{TInv} C_{T H}^{m}\right)$, which concurs with the sum of building cost, plant costs and processing costs, a single $\mathrm{TH}$, corresponding to the lifetime of the whole investment, must be identified. To this end, we proceeded by limiting the analysis of cost of the building in the short term, equal to $m$ years, which coincides with the time horizon of the plant.

Therefore, the building depreciation value (D), referring to TH equal $m$ years, was quantified through the following formula developed by the "Fédération des Expertscomptables Européens (FEE)" (Viel et al., 1991):

$$
D=\frac{(A+20)^{2}}{140}-2.86
$$

where, $\mathrm{A}=$ Percentage rate between the building age and its useful life (expressed in years).

The terminal value of the building $\left(B T V_{T H}^{m}\right)$ was calculated using the following relation:

$$
B T V_{T H}^{m}=B A C_{0}-\left(D_{T H}^{m} \times B A C_{0}\right)
$$

Therefore, the Equation (4) becomes:

$T B C_{T H}^{m}=B A C_{0}+\sum_{j=1}^{m} \frac{B O C_{j}}{(1+r)^{j}}-\frac{B T V_{m}}{(1+r)^{m}}$

Therefore, the Total Investment Cost $\left(\operatorname{TInv} C_{T H}^{m}\right)$ is expressed by the following relationship:

$\operatorname{TInv} C_{T H}^{m}=B T C_{T H}^{m}+M n C_{T H}^{m}$

Concerning the LCC implementation to the case study (Fig. 2), a useful life of 60 years (TH equal to $n$ ) for the building component was assumed, while a useful life of 20 years (TH equal $m$ ) was hypothesized for the plant component; the latter $\mathrm{TH}$ representing the whole investment period, according to the equations previously described. The building considered in this analysis is a basement adequately adapted, with a surface of about $120 \mathrm{~m}^{2}$, able to contain the laboratory facilities.

The costs generated by the building management include the energy costs for the lighting system and the maintenance costs. For year $20^{\text {th }}$, finally, it was necessary to determine the terminal value of the building using the Equation (8). Regarding the plant component, the acquisition cost is equal to the total purchase cost of machinery and equipment for the extraction and packaging of honey (i.e., one honey extractor; one uncapping machine; one cappings press; one honey pump; one filling machine; one pneumatic air-compressor; one dehumidifier; one uncapping tray; one sump tank; one transpallet; six honey ripeners of $400 \mathrm{~kg}$ capacity; minor equipement).

The plant management includes the variable costs, utilities and energy costs hare, while fixed costs are related to the share of machines maintenance and taxes, as well as consulting costs and technical and external services. Variable costs were calculated by considering one honey extractor, with a maximum capacity of 5 honeycombs, that produces, on average, $50 \mathrm{~kg}$ of honey. 


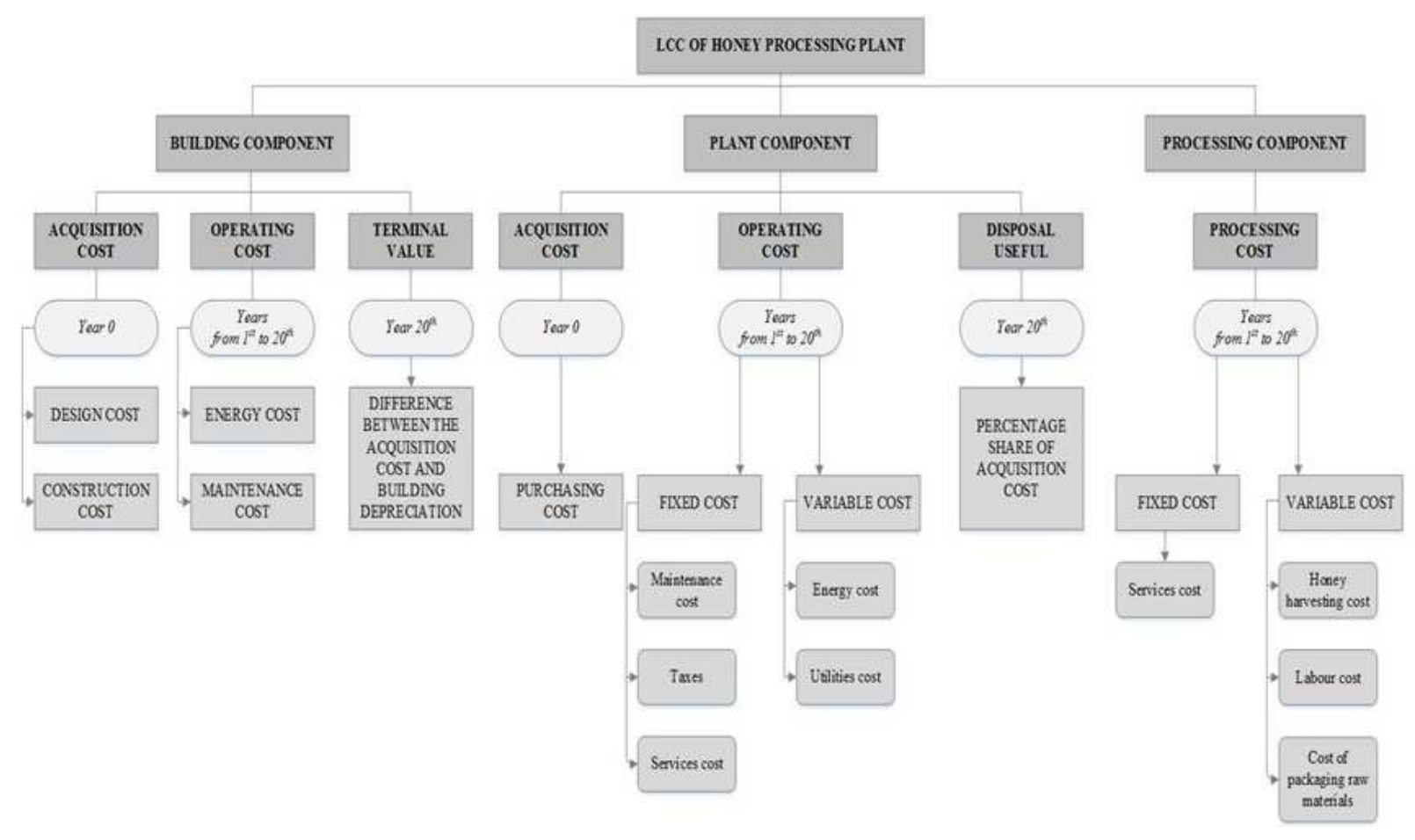

Fig. 2. Case study LCC framework

In addition, it was assumed that the plant, which is used at an optimal level, annually, make an average of 150 honey extraction operations (The period of honey extraction corresponds to the months of May, June, July and September), producing about 7,500 kg of honey (This production amount was calculated by considering a number of 150 active beehives; it should be noted that the production of honey is characterized by a seasonal fluctuation period of production in relation to climatic conditions and other external factors (degree of flowering, frequency of diseases, etc.). Net profit (This value was estimated as demolition material selling: steel, iron, wood) for plant disposal, calculating for the year $20^{\text {th }}$, was estimated at $10 \%$ of the initial purchase cost. Among the variable costs concerning the processing component, the following items of expenditure were considered: The costs related to the production of the honeycombs obtained in the harvesting phase in campaign; the costs of transport and labour, the latter divided into the honey extraction operations, storage and packaging; the purchase costs of raw materials for the packaging and sale.

The work remuneration for entrepreneur and his family was quantified in terms of opportunity cost and was equalize to the employment of temporary workers, by counting the number of hours per year to perform the operations and by adopting an average salary of $8 €$ hour $^{-1}$, including social security contributions. About the remuneration of intellectual work, a percentage equal to $5 \%$ of the saleable production was applied.
Fixed costs include the consulting expenses, certification costs and membership fees.

Commercial prices of honey used in the analysis refers to 2011. In order to actualize the cash flows, a discount rate of $1.8 \%$ was chosen because can be comparable to the profitability of alternative investments with equal risk and duration. Furthermore, due to the economic conditions of recent years, it is preferable not to consider the average inflation rate in order to limit the increase of uncertainty degree of results.

Finally, to assess the profitability of the investment, economic indices were used: The Net Present Value (NPV), the ratio between Benefits and Costs $\left(\mathrm{B}_{0} / \mathrm{C}_{0}\right)$ and the Internal Rate of Return (IRR) (Sgroi et al., 2015).

\section{Results and Discussion}

\section{Results of LCC and Profitability Evaluation}

The application of LCC analysis has allowed to calculate all investment costs related to the honey production in the case-study. Tables from 1 to 4 summarize the main economic results. Specifically, the findings showed that the investment generates an annual operating cost very low for both the building and plant components, although the first involves a large initial outlay due to the construction costs.

Costs linked to the processing component have the greater weight including the production expenses related to the field phase. Therefore, the present value of the investment total cost amounts to $€ 440,009.96$ (Table 4). 
Table 1. LCC of the building component $(€)$

\begin{tabular}{lllll}
\hline & Time Horizon (years) & & \\
& 0 & from $1^{\text {st }}$ to $10^{\text {th }}$ & from $11^{\text {th }}$ to $20^{\text {th }}$ & $20^{\text {th }}$ \\
\hline Building Design Cost $\left(\mathrm{BDC}_{0}\right)$ & $1,000.00$ & - & - & - \\
Building Construction Cost $\left(\mathrm{BCD}_{0}\right)$ & $104,000.00$ & - & - & - \\
Building Operating Cost $\left(\mathrm{BOC}_{\mathrm{j}}\right)$ & - & 662.50 & 925.00 & - \\
Building Terminal Value $\left(\mathrm{BTV}_{20}\right)$ & - & - & - & $86,669.67$ \\
Building Terminal Value (discounted) & $60,661.28$ & - & - & - \\
Building Operating Cost (discounted) & $13,038.31$ & - & - & - \\
Total Building Cost (discounted) & $57,377.03$ & - & - \\
\hline
\end{tabular}

Table 2. LCC of the plant component $(€)$

\begin{tabular}{llll}
\hline & Time Horizon (years) & & \\
& -0 & from $^{\text {st }}$ to $20^{\text {th }}$ & - \\
\hline Plant Acquisition Cost $\left(\mathrm{PlDC}_{0}+\mathrm{PlCC}_{0}\right)$ & $17,912.80$ & - & - \\
Plant Operating Variable Cost $\left(\mathrm{PlOVC}_{\mathrm{j}}\right)$ & - & 381.51 & - \\
Plant Operating Fixed Cost $\left(\mathrm{PlOFC}_{\mathrm{j}}\right)$ & - & $1,233.00$ & - \\
Plant Operating Cost $\left(\mathrm{PlOC}_{\mathrm{j}}\right)$ & - & $1,614.51$ & - \\
Plant Disposal Useful (PlDU & & - & - \\
Plant Disposal Useful (discounted) & - & - & - \\
Plant Operating Cost (discounted) & $1,253.74$ & - & - \\
Total Plant Cost (discounted) & $26,916.31$ & - & - \\
\hline
\end{tabular}

Table 3. LCC of the processing component $(€)$

\begin{tabular}{|c|c|c|c|}
\hline & \multicolumn{3}{|c|}{ Time Horizon (years) } \\
\hline & 0 & from $1^{\text {st }}$ to $20^{\text {th }}$ & $20^{\text {th }}$ \\
\hline Processing Variable Cost $\left(\operatorname{PrVC}_{j}\right)$ & - & $19,517.60$ & - \\
\hline Processing Fixed Cost $\left(\mathrm{PrFC}_{\mathrm{j}}\right)$ & - & 820.00 & - \\
\hline Processing Total Cost $\left(\operatorname{Pr} T C_{T H}^{m}\right)$ & - & $20,337.60$ & - \\
\hline Total Processing Cost (discounted) & $339,057.56$ & - & - \\
\hline
\end{tabular}

Table 4. Total cost of investment in honey production $(€)$

\begin{tabular}{llll}
\hline & Time Horizon (years) & & \\
& - & from $1^{\text {st }}$ to $20^{\text {th }}$ & $20^{\text {th }}$ \\
\hline Manufacturing cost of production $($ discounted $)\left(\mathrm{MnC}_{0}\right)$ & 0 & - & - \\
Total Building Cost (discounted) $\left(\mathrm{TBC}_{0}\right)$ & $57,377.03$ & - & - \\
Total Investment Cost (discounted) $\left(\mathrm{TInv}_{0}\right)$ & $440,009.96$ & - & - \\
\hline
\end{tabular}

In order to evaluate the profitability and economic viability of the investment through the elaboration of economic indices, it was necessary to determine the cash inflows, which correspond to the Gross Marketable Production (GMP), obtained from the quantity of honey sold times the market price.

The average annual production of honey was considered equal to $7,500 \mathrm{~kg}$, in line with the average data recorded in the territorial survey previously conducted. Moreover, the following allocation of the product, destined to different channels sales, was assumed: $6 \%$ to the wholesale, $25 \%$ to the mass retail market and the remaining $10 \%$ to retail. Commercial prices of honey used in the analysis refers to 2011. Results show an average annual GMP equal to $€$
$30,192.08$ and an equivalent in present value terms of $€$ 503,346.29 (Table 5). Considering the discounted cash flows, findings reveal a positive NPV amounting to $€$ $63,336.33$, which demonstrates the profitability of the investment project in terms of returns on invested capital above. In other words, the net profits are able to repay the initial outlay and remunerate the invested capital. Considering the NPV trend as function of the discount rate, the IRR is equal to $5.26 \%$ that is superior to the discount rate (r), so the investment is convenient because its internal profitability is higher than the opportunity cost of capital (Fig. 3). Also in terms of ratio between Benefits and Costs $\left(B_{0} / C_{0}\right)$, the investment appear economically advantageous, by recording a value equal to 1.13 . 


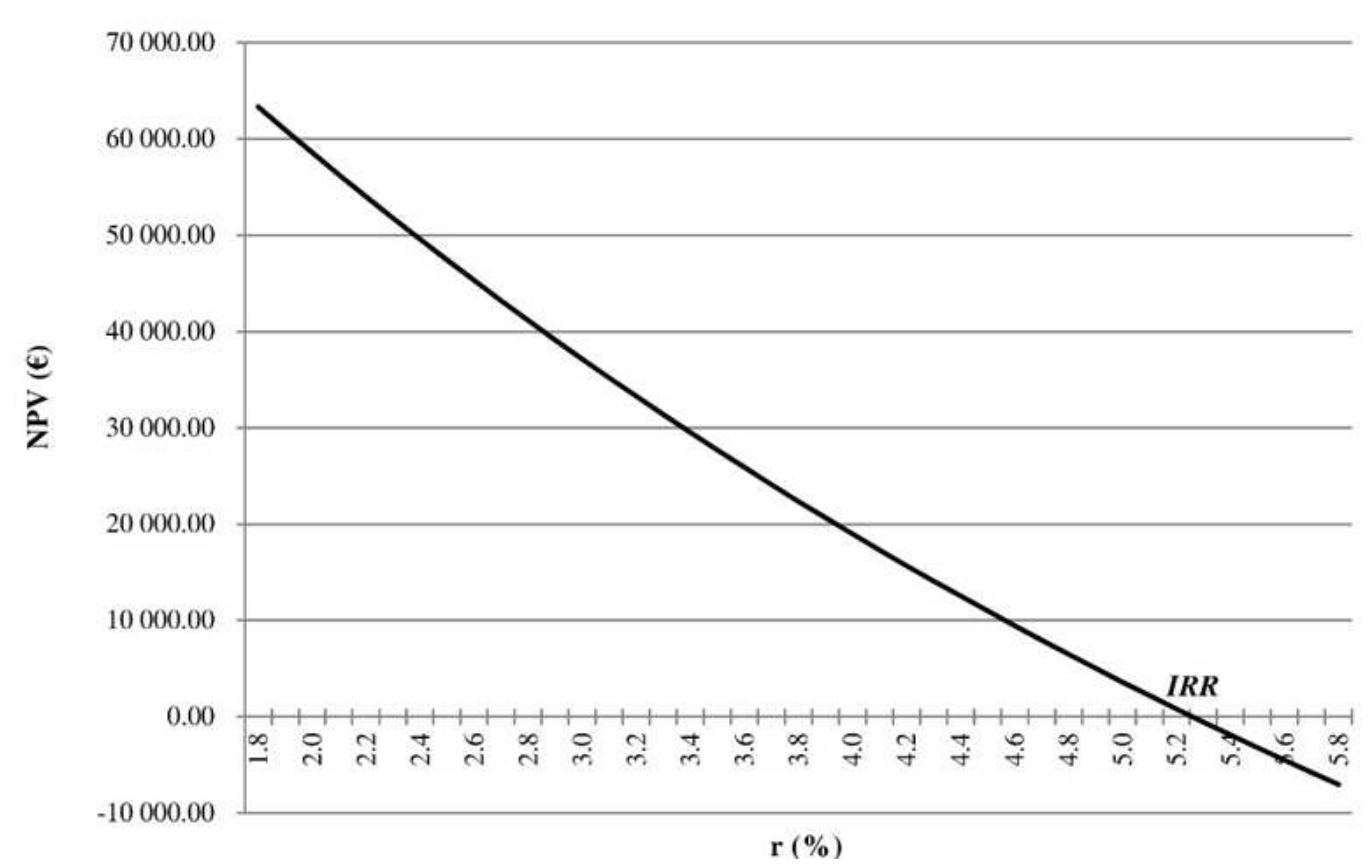

Fig. 3. Trend of the Net Present Value (NPV) as a function of discount rate and identification of Internal Rate of Return (IRR)

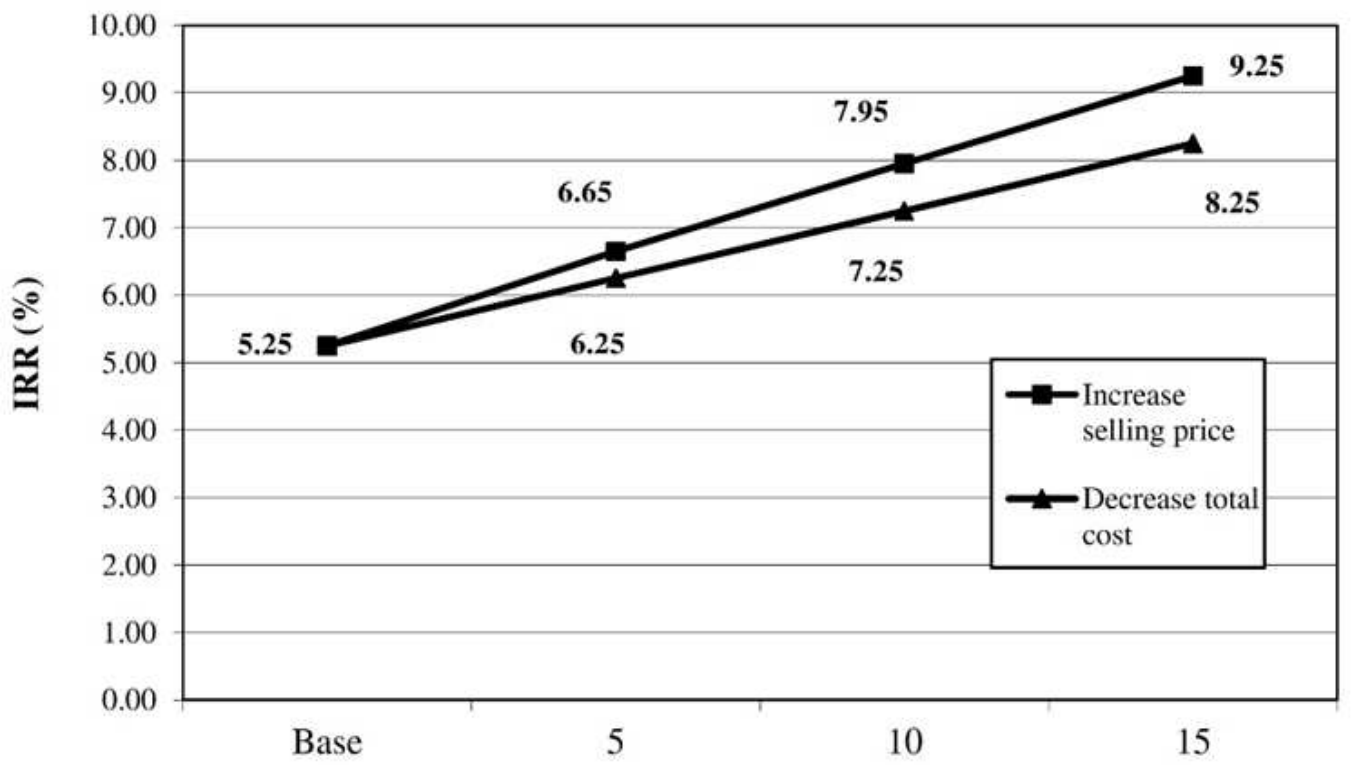

Scenarios (variations of $\pm 5 \%, \pm 10 \%, \pm 15 \%$ )

Fig. 4. Trend of Internal Rate of Return (IRR) considering "positive scenarios"

\section{Sensitivity Analysis}

To verify the assessment previously conducted, several simulations of alternative scenarios were performed both in terms of "positive changes", i.e., an increase of the honey selling price and a decrease of the total cost (plant operating cost and processing cost) and "negative changes", i.e., a decrease of the selling price and an increase of the total cost.

Changes of 5, 10 and 15\% were assumed for the simulations, compared to the baseline scenario, combining data with five different discount rates, ranging from 1.4 and $2.2 \%$, with a variation by $0.2 \%$ points between two subsequent elaborations. 
Table 5. Gross Marketable Production (GMP) analysis

\begin{tabular}{|c|c|c|c|c|c|c|c|}
\hline \multirow[b]{2}{*}{ Honey type } & \multicolumn{3}{|c|}{ Average selling price in $2011\left(€ \mathrm{~kg}^{-1}\right)$} & \multicolumn{3}{|c|}{ Average quantity produced (kg) } & \multirow[b]{2}{*}{$\begin{array}{l}\text { Average annua } \\
\text { GMP }(€)\end{array}$} \\
\hline & Wholesale & $\begin{array}{l}\text { Mass retail } \\
\text { market }\end{array}$ & Retail & Wholesale & $\begin{array}{l}\text { Mass retail } \\
\text { market }\end{array}$ & Retail & \\
\hline Wildflower & 2.70 & 6.00 & 6.80 & $1,928.33$ & 741.67 & 296.67 & $11,673.83$ \\
\hline Citrus (oranges) & 3.00 & 6.00 & 6.80 & $1,245.83$ & 479.17 & 191.67 & $7,915.83$ \\
\hline Eucalyptus & 3.00 & 6.00 & 6.80 & 736.67 & 283.33 & 113.33 & $4,680.67$ \\
\hline Sulla & 2.70 & 6.00 & 6.80 & 725.83 & 262.50 & 128.33 & $4,407.42$ \\
\hline Chestnut & 3.00 & 6.00 & 6.80 & 238.33 & 91.67 & 36.67 & $1,514.33$ \\
\hline Total GMP & & & & & & & $30,192.08$ \\
\hline Discounted GMP & & & & & & & $503,346.29$ \\
\hline
\end{tabular}

Table 6. Difference between the values of economic indicators considering the "positive scenarios" per several discount rates

\begin{tabular}{|c|c|c|c|c|c|c|c|c|c|c|}
\hline \multirow[b]{3}{*}{$\begin{array}{l}\text { Positive changes scenarios } \\
\text { Increase selling price }\end{array}$} & \multicolumn{10}{|c|}{ Discount rate } \\
\hline & \multicolumn{2}{|l|}{$1.4 \%$} & \multicolumn{2}{|l|}{$1.6 \%$} & \multicolumn{2}{|l|}{$1.8 \%$} & \multicolumn{2}{|l|}{$2.0 \%$} & \multicolumn{2}{|l|}{$2.2 \%$} \\
\hline & $\begin{array}{l}\mathrm{NPV} \\
{[€]}\end{array}$ & $\mathrm{B}_{0} / \mathrm{C}_{0}$ & $\begin{array}{l}\mathrm{NPV} \\
{[€]}\end{array}$ & $\mathrm{B}_{0} / \mathrm{C}_{0}$ & $\begin{array}{l}\mathrm{NPV} \\
{[€]}\end{array}$ & $\mathrm{B}_{0} / \mathrm{C}_{0}$ & $\begin{array}{l}\mathrm{NPV} \\
{[€]}\end{array}$ & $\mathrm{B}_{0} / \mathrm{C}_{0}$ & $\begin{array}{l}\mathrm{NPV} \\
{[€]}\end{array}$ & $\mathrm{B}_{0} / \mathrm{C}_{0}$ \\
\hline Base (prices 2011) & $73,343.12$ & 1.14 & $68,252.77$ & 1.13 & $63,336.33$ & 1.13 & $58,587.10$ & 1.12 & $53,998.65$ & 1.11 \\
\hline$+5 \%$ & $99,518.28$ & 1.19 & $93,916.92$ & 1.18 & $88,503.64$ & 1.18 & $83,271.29$ & 1.17 & $78,212.98$ & 1.16 \\
\hline$+10 \%$ & $125,693.43$ & 1.24 & $119,581.07$ & 1.23 & $113,670.96$ & 1.23 & $107,955.48$ & 1.22 & $102,427.31$ & 1.21 \\
\hline$+15 \%$ & $151,868.59$ & 1.29 & $145,245.21$ & 1.29 & $138,838.27$ & 1.28 & $132,639.67$ & 1.27 & $126,641.64$ & $1.26 \backslash$ \\
\hline \multicolumn{11}{|l|}{ Decrease total cost } \\
\hline Base & $73,343.12$ & 1.14 & $68,252.77$ & 1.13 & $63,336.33$ & 1.13 & $58,587.10$ & 1.12 & $53,998.65$ & 1.11 \\
\hline$-5 \%$ & $92,374.60$ & 1.19 & $87,744.68$ & 1.18 & $81,635.02$ & 1.17 & $76,534.52$ & 1.16 & $72,389.42$ & 1.15 \\
\hline$-10 \%$ & $112,209.95$ & 1.23 & $106,360.82$ & 1.23 & $100,706.64$ & 1.22 & $95,240.03$ & 1.21 & $89,953.90$ & 1.20 \\
\hline$-15 \%$ & $131,196.77$ & 1.29 & $124,920.07$ & 1.28 & $118,962.40$ & 1.27 & $113,145.34$ & 1.26 & $107,518.38$ & 1.25 \\
\hline
\end{tabular}

Table 7. Difference between the values of economic indicators considering the "negative scenario" per several discount rates

\begin{tabular}{|c|c|c|c|c|c|c|c|c|c|c|}
\hline \multirow[b]{3}{*}{$\begin{array}{l}\text { Negative changes scenarios } \\
\text { Decrease selling price }\end{array}$} & \multicolumn{10}{|c|}{ Discount rate } \\
\hline & \multicolumn{2}{|l|}{$1.4 \%$} & \multicolumn{2}{|l|}{$1.6 \%$} & \multicolumn{2}{|l|}{$1.8 \%$} & \multicolumn{2}{|l|}{$2.0 \%$} & \multicolumn{2}{|l|}{$2.2 \%$} \\
\hline & $\begin{array}{l}\mathrm{NPV} \\
{[€]}\end{array}$ & $\mathrm{B} 0 / \mathrm{C} 0$ & $\begin{array}{l}\text { NPV } \\
{[€]}\end{array}$ & $\mathrm{B} 0 / \mathrm{C} 0$ & $\begin{array}{l}\mathrm{NPV} \\
{[€]}\end{array}$ & $\mathrm{B} 0 / \mathrm{C} 0$ & $\begin{array}{l}\mathrm{NPV} \\
{[€]}\end{array}$ & $\mathrm{B} 0 / \mathrm{C} 0$ & $\begin{array}{l}\mathrm{NPV} \\
{[€]}\end{array}$ & $\mathrm{B} 0 / \mathrm{C} 0$ \\
\hline Base (prices 2011) & $73,343.12$ & 1.14 & $68,252.77$ & 1.13 & $63,336.33$ & 1.13 & $58,587.10$ & 1.12 & $53,998.65$ & 1.11 \\
\hline$-5 \%$ & $47,167.97$ & 1.09 & $42,588.63$ & 1.08 & $38,169.02$ & 1.08 & $33,902.90$ & 1.07 & $29,784.32$ & 1.06 \\
\hline$-10 \%$ & $20,992.82$ & 1.04 & $16,924.48$ & 1.03 & $13,001.70$ & 1.03 & $9,218.71$ & 1.02 & $5,569.99$ & 1.01 \\
\hline$-15 \%$ & $-5,182.34$ & 0.99 & $-8,739.67$ & 0.98 & $-12,165.61$ & 0.98 & $-15,465.48$ & 0.97 & $-18,644.35$ & 0.96 \\
\hline \multicolumn{11}{|l|}{ Increase total cost } \\
\hline Base & $73,343.12$ & 1.14 & $68,252.77$ & 1.13 & $63,336.33$ & 1.13 & $58,587.10$ & 1.12 & $53,998.65$ & 1.11 \\
\hline$+5 \%$ & $54,311.65$ & 1.10 & $50,512.39$ & 1.10 & $45,037.64$ & 1.09 & $40,639.67$ & 1.08 & $37,260.45$ & 1.07 \\
\hline$+10 \%$ & $36,262,69$ & 1.07 & $31,896.25$ & 1.06 & $27,683,63$ & 1.05 & $23,618.80$ & 1.04 & $19,695.97$ & 1.04 \\
\hline$+15 \%$ & $17,275.88$ & 1.03 & $13,280,11$ & 1.02 & $9,427.88$ & 1.02 & $5,713.49$ & 1.01 & $21,31.49$ & 1.00 \\
\hline
\end{tabular}

The adoption of a range of discount rates allows overcoming the uncertainty related to the choice of a single rate.

For all scenarios identified the values of NPV, the benefit/cost ratio and IRR were calculated. By observing the results of the simulations carried out in the case of "positive changes" (Table 6), NPV values and B0/C0 remain positive for all scenarios. However, an analysis of variances shows that, ceteris paribus, the price change has a more significant influence on economic performance with respect to the variation of the cost. Similar results are recorded by analysing the return on investment in terms of IRR. By examining the trend (Fig. 4) in relation to the scenarios, it is possible to observe that in the hypothesis of price increase, the values are always higher than those related to the corresponding costs reductions. The results analysis carried out by assuming "negative changes" (Table 7) shows that NPV and $\mathrm{B}_{0} / \mathrm{C}_{0}$ have positive values in all scenarios simulated through cost increases, while, in the case of a reduction of prices, the indices remained positive for variations of 5 and $10 \%$ and became negative for variations of $15 \%$. In this latter case, therefore, the investment is not economically viable. The analysis of deviations shows how a cost increase has less impact than a similar decrease in prices. However, it is necessary to underline that the prices variation can represent an aleatory hypothesis due, from one side, to the unpredictable market behaviours and, from the other, to extra costs of marketing supporting by firm. Instead, results from scenarios of cost variation are subject to a minor uncertainty since only factors inside of firm are considered (e.g., as an improvement of organization and management of resources). 


\section{Conclusion}

The Life Cycle Costing (LCC) approach applied to the honey production proves to be a useful instrument to support decision-making in corporate investment decisions, as it allows a more thorough assessment of the costs incurred during the entire life cycle of the project. LCC appraisal allows to design and plan specific interventions to optimize the production process with the aim to devise new investments or for the maintenance and improvement of an existing production structure. Furthermore, the joint use of LCC and NPV and IRR indicators allows a more deepened profitability assessments of an investment and in combination with LCA it may be a useful tool both for public decisionmakers and entrepreneurs who want to pursue environmental-friendly strategies. The LCC implementation carried out in this study made it possible to assess the economic viability of a productive investment applied to a small-scale agro-food chain, proving the exportability of this method to other similar production systems. In the case of firm investments for honey production, for which the economic analysis not frequently appear in literature, the application of method permits to evaluate not only every component (plant and building), but also the cost of manufacturing process including the processing phase.

Results showed the weight of each item cost; in particular, the start-up costs and processing variable costs generate greater investment expenses. However, the cash inflows obtained from the sale of different honey typologies are able to cover, satisfactorily, the investment costs.

Furthermore, the findings of the profitability analysis demonstrate the economic viability of the investment being able to create value throughout the life of the project and generate an appropriate level of profitability. The in sourcing of processing phase by the farm makes possible to intercept value-added and, consequently, to increase the profit. Obviously, the investment would be far more advantageous, in absolute terms, if the assessments were carried out in terms of net income (i.e., the return to farm operators for their labour, management and capital, after all production expenses have been paid), even more so considering that the beekeeping context analysed is characterized by family-run business.

The survey carried out suggests, all at once, the need for greater enhancement in the honey production (e.g., by adopting modern technologies and high quality standards), in order to obtain an appropriate market price, which would make even more advantageous the investments. However, this latter achievement could be reinforced by increasing, in further researches, the sample representativeness in terms of firm's number, class sizes, production systems (organic and conventional) and territorial positioning.

\section{Funding Information}

This work is a part of the Research Project "Agreement Framework Program" - Action 3 "ARAC Miele" supported by the Department n. 11-Culture, Education, Universities, Research, Technological Innovation, High training of Calabria Region, Italy.

Furthermore, this work was funded by Italian Ministry of Research and University (MIUR) and European Commission (Project PON01_00636: Anticounterfeiting technologies and materials and nanotechnologies for authentication and protection of agrifood excellence-“Fingerimball").

\section{Author's Contributions}

This study is a result of the full collaboration of all authors.

Alfio Strano: Wrote the paragraph "Sensitivity analysis".

Teodora Stillitano: Wrote the paragraphs "Life Cycle Costing (LCC) and profitability evaluation of investments" and "Results of LCC and profitability evaluation".

Anna Irene De Luca: Wrote the paragraph "Introduction".

Giacomo Falcone: Wrote the paragraph "Case Study".

Giovanni Gulisano: Wrote the paragraph "Conclusions".

\section{Ethics}

The authors have not conflicts of interest in the development and publication of current research.

\section{References}

Bailey, K.D., 1994. Methods of Social Research. 1st Edn., Simon and Schuster, New York.

ISBN-10: 0029012791, pp: 588.

Ćejvanović, F., Z. Grgić, A. Maksimović and D. Bićanić, 2011. Assumptions of economic model for sustainable productions of beekeeping in the Bosnia and Hercegovina. J. Agric. Sci. Technol., 5: 481-495.

Ciroth, A., K. Vergheseand and C. Trescher, 2008. A Survey of Current Life Cycle Costing Studies. In: Environmental Life Cycle Costing, Hunkeler, D., K. Lichtenvort and G. Rebitzer (Eds.)., CRC Press, Pensacola, ISBN-10: 1420054732, pp: 91-111.

De Gennaro, B., B. Notarnicola, L. Roselli and G. Tassielli, 2012. Innovative olive-growing models: An environmental and economic assessment. J. Cleaner Production, 28: 70-80.

DOI: $10.1016 / j$ j.jclepro.2011.11.004 
De Luca, A.I., G. Falcone, T. Stillitano, A. Strano and G. Gulisano, 2014. Sustainability assessment of quality-oriented citrus growing systems in Mediterranean area. Quality-Access Success, 15: 103-108.

De Luca, A.I., N. Iofrida, A. Strano, G. Falcone and G. Gulisano, 2015. Social life cycle assessment and participatory approaches: A methodological proposal applied to citrus farming in Southern Italy. Integrated Environ. Assessment Manage., 11: 383-396.

DOI: $10.1002 /$ ieam. 1611

Dhillon, B.S., 1989. Life Cycle Costing: Techniques, Models and Applications. 1st Edn., Psychology Press, ISBN-10: 2881243029, pp: 353.

Falcone, G., A. Strano, T. Stillitano, A.I. De Luca and N. Iofrida et al., 2015. Integrated sustainability appraisal of wine-growing management systems through LCA and LCC methodologies. Chem. Eng. Trans., 44: 223-228. DOI: 10.3303/CET1544038

FAO, 2015. FAOSTAT Statistics Division.

Folayan, J.A. and J.O. Bifarin, 2013. Profitability analysis of honey production in Edo North local government area of Edo State, Nigeria. J. Agric. Economics Develop., 2: 060-064.

Fotso Kenmogne, P.R., F. Meutchieye, S.I. Andriamanalina, A. Youbissi and J. Tchoumboué et al., 2014. Socio-economic and technical characteristics of beekeeping in the departments of bamboutos, MiFi and Menoua in Western Cameroon. Livestock Res. Rural Develop.

Gluch, P. and H. Baumann, 2004. The Life Cycle Costing (LCC) approach: A conceptual discussion of its usefulness for environmental decision-making. Building Environ., 39: 571-580. DOI: 10.1016/j.buildenv.2003.10.008

Hilmi, M., N. Bradbear and D.J. Mejía-Lorío, 2011. Beekeeping and Sustainable Livelihoods. 2nd Edn., Rural Infrastructure and Agro-Industries Division, Food and Agriculture Organization of the United Nations, Rome, ISBN-10: 9251070628, pp: 72.

Huppes, G., M. van Rooijen, R. Kleijn, R. Heijungs and A. de Koning et al., 2004. Life cycle costing and the environment. Report of a Project Commissioned by the Ministry of VROM-DGM for the RIVM Expertise Centre LCA.

Iotti, M. and G. Bonazzi, 2014a. Life cycle flow analysis: Methodological improvement and application to the Parma PDO ham sector. Quality Access Success, 15: 98-103.

Iotti, M. and G. Bonazzi, 2014b. The application of Life Cycle Cost (LCC) approach to quality food production: A comparative analysis in the Parma PDO ham sector. Am. J. Applied Sci., 11: 1492-1506. DOI: 10.3844/ajassp.2014.1492.1506
ISO, 2008. BS ISO 15686-5:2008-Buildings and constructed assets. Service Life Planning. Life Cycle Costing, ISO.

ISTAT, 2010a. IV Agricultural census.

ISTAT, 2010b. Valore aggiunto ai prezzi di base dell'agricoltura per regione. ISTAT-Istituto nazionale di statistica.

Lichtenvort, K., G. Rebitzer, G. Huppes, A. Ciroth and S. Seuring et al., 2008. History of Life Cycle Costing, Its Categorization and Its Basic Framework. In: Environmental Life Cycle Costing, Hunkeler, D., K. Lichtenvort and G. Rebitzer (Eds.)., CRC Press, Pensacola, ISBN-10: 9781420054705, pp: 1-16.

Marotta, G. and C. Nazzaro, 2012. Value portfolio in the multifunctional farm: New theoreticalmethodological approaches. Rivista di Economia Agraria, 2: 1-30. DOI: 10.3280/REA2012-002001

Mogni, F., H. Palau, C. Tresoldi, S. Senesi and F. Vilella, 2009. Sustainable development in food and agribusiness: Application of the theoretical model to the Argentine beekeeping sector. VII International PENSA Conference, Nov. 26-28, Sao Paulo, Brazil, pp: 1-16.

Mohamad, R.S., V. Verrastro, G. Cardone, M. R. Bteich and M. Favia et al., 2014. Optimization of organic and conventional olive agricultural practices from a life cycle assessment and life cycle costing perspectives. J. Cleaner Production, 70: 78-89. DOI: 10.1016/j.jclepro.2014.02.033

Nazzi, F., D. Annoscia, S. Del Fabbro and F. Del Piccolo, 2014. Research and education for sustainability in a beekeeping project in sub-Saharan Africa. Environ. Develop. Sustainability, 16: 619-632. DOI: 10.1007/s10668-013-9497-2

Notarnicola, B., E. Settanni and G. Tassielli, 2009. Approcci All'integrazione Dei Costi in LCA: Life Cycle Costing, Analisi Input-Output. In: Atti del Convegno Scientifico della Rete Italiana LCA, Palermo 11 e 12 Giugno, Cappellaro, F. and S. Scalbi (Eds.)., ENEA, Roma, ISBN-10: 978-88-8286-206-0, pp: 17-25.

Notarnicola, B., G. Tassielu and G.M. Nicoletti, 2004. Environmental and economic analysis of the organic and conventional extra-virgin olive oil. New Medit, 2: $28-34$.

Osservatorio Nazionale Miele, 2009. Andamento produttivo e di mercato del miele per la stagione 2009.

Pergola, M., M. D’Amico, G. Celano, A.M. Palese and A. Scuderi et al., 2013. Sustainability evaluation of Sicily's lemon and orange production: An energy, economic and environmental analysis. J. Environ. Manage., 128: 674-682.

DOI: 10.1016/j.jenvman.2013.06.007 
Pocol, C.B., L.A. Marghitas and A.A. Popa, 2012. Evaluation of sustainability of the beekeeping sector in the North West Region of Romania. J. Food, Agric. Environ., 10: 1132-1138.

Pocol, C.B., M. Ilea and A.A. Popa, 2011. Economic diagnosis of beekeeping in the North West region of Romania: A case study of Cluj County. Analele UniversităŃii din Oradea, Fascicula: Ecotoxicologie, Zootehnie şi Tehnologii de Industrie Alimentară, 0: 279-286.

Ragusa, S. and A. Russo, 1989. I Problemi Dell'apicoltura In Calabria. In: Atti del Convegno "I Problemi dell'apicoltura in Calabria, Ragusa, S. and A. Russo (Eds.)., Reggio Calabria, 22 giugno, Laruffa, Reggio Calabria, Italy, pp: 13-16.

Rebitzer, G. and S. Seuring, 2003. Methodology and application of life cycle costing. Int. J. LCA, 8: 110-111. DOI: 10.1007/BF02978436

Regione Calabria, 2010a. Programma triennale 20102013, sottoprogramma Regione Calabria "Attuazione dei regolamenti comunitari sul miglioramento della produzione e commercializzazione dei prodotti dell'apicoltura".

Regione Calabria, 2010b. Albo Regionale Apicoltori Calabria. Anni 2008, 2009 e 2010

Saner, G., S. Engindeniz, B. Tolon and F. Cukur, 2003. The economic analysis of beekeeping enterprise in sustainable development: A case study of Turkey. Apiacta, 4: 1-6.

Sgroi, F., M. Foderà, A.M. Di Trapani, S.Tudisca and R. Testa, 2015. Cost-benefit analysis: A comparison between conventional and organic olive growing in the Mediterranean Area. Ecol. Eng., 82: 542-546. DOI: 10.1016/j.ecoleng.2015.05.043
Sotte, F., 2006. L'impresa agricola alla ricerca del valore. Agriregionieuropa.

Strano, A., A.I. De Luca, G. Falcone and G. Gulisano, 2013a. Economic and Environmental Sustainability Assessment of Clementine Crops Scenarios in Calabria. In: Sustainability of the Agri-Food System: Strategies and Performances: Proceedings of the 50th SIDEA Conference, De Gennaro, B. and G. Nardone, (Eds.), ISBN-10: 8897683606, pp: 354-354.

Strano, A., A.I. De Luca, G. Falcone, N. Iofrida and T. Stillitanoand et al., 2013b. Economic and environmental sustainability assessment of wine grape production scenarios in Southern Italy. Agric. Sci., 4: 12-20. DOI: 10.4236/as.2013.45B003

Sturiale, C., 1989. Aspetti Economici del Settore Apistico. In: Atti del Convegno "I problemi dell'apicoltura in Calabria”, Reggio Calabria, 22 Giugno, Ragusa, S. and A. Russo (Eds.)., Laruffa, Reggio Calabria, Italy, pp: 51-69.

Van der Ploeg, J.D., 2006. Oltre la Modernizzazione. Processi di Sviluppo Rurale in Europa. 1st Edn., Rubbettino, ISBN-10: 884981609X, pp: 146.

Van der Ploeg, J.D., A. Long and J. Banks, 2002. Living Countrysides: Rural Development Processes in Europe. The State of the Art. 1st Edn., Elsevier, ISBN-10: 9054391170, pp: 231.

Viel, J., O. Bredt and M. Renard, 1991. La valutazione delle aziende e delle parti di azienda. Etas libri, Milano. 